\title{
Cultural capital in undergraduate research: an exploration of how biology students operationalize knowledge to access research experiences at a large, public research-intensive institution
}

\author{
Katelyn M. Cooper ${ }^{1 *}$ D, Jacqueline M. Cala ${ }^{2}$ and Sara E. Brownell ${ }^{3}$
}

\begin{abstract}
Background: Undergraduate research experiences are becoming essential for pursuing future opportunities in science, but little has been done to identify what factors predict which students get to participate in research and which students do not. In this manuscript, we propose "scientific research capital" and specifically "scientific research cultural capital" as constructs to explain what students may need to know and do in order to successfully engage in an undergraduate research experience. We begin to articulate what comprises one component of scientific research cultural capital, embodied cultural capital, by identifying the knowledge that students may need to have in order to obtain an undergraduate research experience at a large, research-intensive institution where there are many more undergraduates vying for research positions than opportunities available. We interviewed 43 researchers, defined as undergraduates who had participated in research, and 42 non-researchers, defined as undergraduates who were interested in participating in research but had not yet successfully obtained a position, in a biology department at an R1 institution. We analyzed the data using inductive coding.
\end{abstract}

Results: We identified 10 "rules of research" or aspects of scientific research cultural capital that undergraduates reported about finding and securing undergraduate research. We used logistic regression to test whether undergraduate researchers were more likely than non-researchers to know particular rules. Researchers were more likely than non-researchers to know rules about securing research opportunities.

Conclusions: Since researchers were more likely than non-researchers to know rules related to securing research, educating students about how to secure research experiences and encouraging faculty to re-examine the criteria they use to admit students into their labs may be a key step in leveling the playing field for students who are vying for research positions. We propose that the construct of scientific research cultural capital can help publicize the hidden curriculum of undergraduate research so that students can more equitably gain access to undergraduate research.

Keywords: Undergraduate research experience, Undergraduate research, Capital, Cultural capital, Scientific research capital, Embodied cultural capital, Rules of research, Hidden curriculum

\footnotetext{
* Correspondence: Katelyn.cooper@asu.edu

${ }^{1}$ Research for Inclusive STEM Education Center, School of Life Sciences,

Arizona State University, 451 E. Tyler Mall, Tempe, AZ 85281, USA

Full list of author information is available at the end of the article
} 


\section{Introduction}

\section{The potential impact of undergraduate research on} students

Participating in undergraduate research is arguably one of the most lucrative activities for a biology student to engage in because of the wide array of benefits that research can provide (American Association for the Advancement of Science, 2011; National Research Council, 2003, 2012; Olson \& Riordan, 2012). Students have reported that participating in undergraduate research helps them gain an understanding of the research process, develop tolerance for obstacles, understand how knowledge is constructed, learn to integrate theory and practice, become a part of a learning community, and develop self-confidence (Lopatto, 2004, 2007). Further, studies have demonstrated that participating in research can enhance student learning (Brownell et al., 2015), as well as students' ability to think critically (Brownell et al., 2015; Ishiyama, 2002) and students' perceptions of career options (Trott, Sample McMeeking, Bowker, \& Boyd, 2020). What is perhaps most impressive is the relationship between engaging in undergraduate research and students' persistence in science. Participating in undergraduate research has been shown to positively influence a student's persistence in undergraduate science, technology, engineering, and math (STEM) degrees (Hernandez, Woodcock, Estrada, \& Schultz, 2018; Jones, Barlow, \& Villarejo, 2010; Rodenbusch, Hernandez, Simmons, \& Dolan, 2016), as well as a student's interest in pursuing a STEM graduate degree (Carter, Mandell, \& Maton, 2009; Eagan Jr. et al., 2013; Russell et al., 2015; Schultz et al., 2011; Seymour, Hunter, Laursen, \& DeAntoni, 2004). Graduate students have reported that undergraduate research experiences helped prepare them for graduate school (Huss, Randall, Patry, Davis, \& Hansen, 2002), and several studies have shown a positive impact of undergraduate research experiences, specifically on the decisions of underrepresented minority students to pursue graduate school (Espinosa, 2011; Hernandez et al., 2018; Villarejo, Barlow, Kogan, Veazey, \& Sweeney, 2008). Further, participating in undergraduate research has been shown to increase students' chances of entering a STEM graduate or professional program (Carter et al., 2009; Hathaway, Nagda, \& Gregerman, 2002; Hernandez et al., 2018; Russell et al., 2015; Seymour et al., 2004), which is unsurprising considering undergraduate research is viewed as a valuable and sometimes required prerequisite for selective science doctoral programs and medical schools (Cooper, Gin, \& Brownell, 2019; Olson \& Riordan, 2012).

Scientists have recognized undergraduate research as a high impact practice and have called for a larger number of undergraduate students to participate in research (American Association for the Advancement of Science,
2011; National Research Council, 2003; Olson \& Riordan, 2012). However, the limited number of research experiences in faculty labs restricts the benefits of undergraduate research to only a select group of students (Olson \& Riordan, 2012; Wood, 2003). While some elite universities, small colleges, and specialized programs may have the ability to provide every undergraduate with a research experience, most degree programs within most institutions likely cannot offer each student the opportunity to join a faculty member's lab. This gap is illustrated by a study of nearly 1000 students spanning two research-focused institutions and two undergraduate-focused institutions; $27 \%$ of students reported participating in research, while $45 \%$ of students reported that they were not participating in research, but wanted to (Mahatmya et al., 2017). While factors that influence which students participate in undergraduate research have been hypothesized (Bangera \& Brownell, 2014), few studies have specifically explored what differentiates the students who do not get to participate in research from those who do.

\section{The path to becoming an undergraduate researcher}

Before we can hypothesize about the factors that separate undergraduate researchers from students who want to be doing research but are not, we need to articulate the path to becoming an undergraduate researcher. Outlining this path allows us to identify points at which students may be thwarted from successfully obtaining an undergraduate research opportunity. While we recognize that students' individual paths to becoming involved in research vary, we outline a common path to undergraduate research for students who actively seek a research opportunity (Fig. 1):

(1) Student must know what research is and that participating in undergraduate research is a possibility.

(2) Student must recognize possible benefits associated with undergraduate research, particularly as these benefits pertain to the student's personal and professional goals.

(3) Student must decide to pursue an undergraduate research position. While the potential benefits of doing undergraduate research may heavily influence a student's desire to do research, they must outweigh the potential costs of participating in research (Ceyhan \& Tillotson, 2020; Cooper, Ashley, \& Brownell, 2017; Wigfield, Tonks, \& Klauda, 2009). Financial and time constraints may limit a student's ability to engage in undergraduate research (Cooper et al., 2019; Mahatmya et al., 2017). 


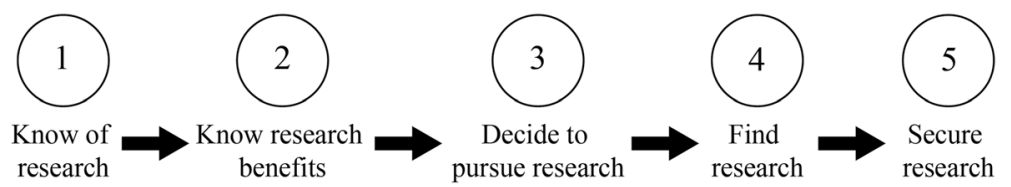

Fig. 1 Common path to obtaining an undergraduate research experience for students who actively seek a research opportunity

(4) Student must find an available research opportunity. At institutions without programs that place students into faculty labs, the onus is on the student to identify available research opportunities.

(5) Once a student identifies an available research opportunity, they must secure the research position. This process is widely variable and often involves an email or verbal exchange between a professor or graduate student and the undergraduate student interested in joining their lab, followed by an interview.

There has been little research on what differentiates students who do not participate in research from those who do participate. Some research has explored the pathways and motivational factors specific to students' decisions to participate in undergraduate research (Mahatmya et al., 2017). In this study, we chose to explore the pathway downstream of students' motivation and study a group of students who have already decided that they want to do undergraduate research. Specifically, we draw from Pierre Bourdieu's theory of capital (Bourdieu, 1977, 1991) to explore what factors may be influencing which students do and do not get to participate in research.

\section{Scientific research capital: a construct to explain differences in which students can obtain and succeed in undergraduate research experiences}

The notion of capital describes the valuable resources in society that can generate social advantage within specific fields, such as science (Bourdieu, 1977; Marx, 1999; Marx \& Engels, 1942). The distribution of capital represents the structure of the social world and determines the chances of success in a particular field. Scientific fields, such as biology, are thought to be particularly competitive and defined by distribution of capital among people and institutions, and as such, individuals with more capital are predicted to accrue higher success and status within a scientific field (Albert \& Kleinman, 2011; Bourdieu, 1991). Bourdieu (1986) described that capital is what makes the "games of society" more complex than simply games of chance. In fact, capital has been likened to the "cards that one has" when playing a particular game and one's "knowledge of the rules of the game," which predict their ability to play the game as well as their ability to win the game (Archer, Dawson, DeWitt, Seakins, \& Wong, 2015; Lareau \& Horvat, 1999).

Capital can be organized into three primary forms which include (1) economic capital or anything that can be immediately converted into money (e.g., property), (2) social capital or the resources gained through relationships, network associations, and group membership, and (3) cultural capital or the knowledge, skills, education, and advantages that further one's success in a particular field (Bourdieu, 1986). It is worth noting that cultural capital is field-specific; that is, if someone has cultural capital in a field, such as the field of science, they have the dispositions to think and act in ways that advance their position or trajectory in science (Edgerton \& Roberts, 2014). It is for this reason that one's cultural capital in one field, for example, in the culture of their home community, may be misaligned with the cultural capital of another field, for example, the culture of academic science. Bourdieu proposed that cultural capital exists in three forms: embodied, objectified, and institutionalized (Bourdieu, 1986). The embodied state refers to long-lasting dispositions of the mind and body. This specialized knowledge accrues over time and is not necessarily easily transferred from one person to another. The objectified state refers to cultural goods such as books, instruments, and machines. These artifacts can be physically given to someone else. Finally, the institutionalized state refers to credentials, including academic credentials such as a degree or letter grade.

The term science capital was described by Archer and colleagues as the social and cultural capital specific to the field of science that is used to further K-12 students' attainment, engagement, and participation in science (Archer et al., 2015; Archer, DeWitt, \& Willis, 2014). Science capital has been shown to be a useful lens for understanding uneven patterns in the degree to which primary and secondary students identify with science and plan to pursue science in the future (Archer et al., 2015; DeWitt, Archer, \& Mau, 2016). However, because this construct was not conceptualized with regard to university students, it did not encompass students' knowledge of undergraduate research experiences.

\section{Capital and undergraduate research experiences}

We hypothesize that students' economic, social, and cultural capital specific to scientific research contribute to 
whether a student is successful in obtaining a research experience as an undergraduate. There is limited research exploring students' capital with regards to obtaining undergraduate research positions and specifically how capital influences uneven patterns in students' participation in undergraduate research. In one study, Thompson, Conaway, and Dolan (2016) explored how students in undergraduate research develop capital through their research experience. Specifically, these researchers explored the experiences of students who were enrolled in a networked research experience, where the students had the opportunity to develop relationships with their faculty research mentors as well as with additional faculty and students working on the same research project at their own institution and at other institutions. With regard to how students accessed the networked research project, the study found that students leveraged cultural, social, and human capital, a type of capital that was not presented in Bourdieu's initial conception of capital (1986). Human capital refers to skills and knowledge that are of value to employers. In this study, students' cultural capital allowed them to recognize the value of research and seek it out; students drew upon their social capital by networking with faculty to learn about the research opportunity as well as asking faculty for references and letters of recommendation (Thompson et al., 2016). While this study provided important insight into how students drew on their existing capital to access a structured research program, it did not identify what capital is necessary for engaging in traditional undergraduate research experiences where students do not enroll in a class or sign up for a program, but instead seek to gain access to an individualized research opportunity without a formal application process or structure to it. Another study of undergraduates who were participating in research found that students in mentoring triads, which differ based on whether an undergraduate, a postgraduate, and a faculty member interact with one another about the undergraduate's research, attain different resources based on the social capital of their triad (Aikens et al., 2016). The study identified that undergraduates who worked with both a postgraduate and a faculty mentor realized greater outcomes than students who worked with only a postgraduate. Additionally, researchers have studied the role that cultural capital plays in faculty recognizing students as budding scientists (Thompson \& Jensen-Ryan, 2018). This study focused exclusively on students who had already gained access to research experiences and found that faculty more easily recognized students as science people when students were interested in scientific research careers and did not have competing family responsibilities. Researchers have also explored which students possess the capital necessary to maximize their research experiences; one study showed that being a first-generation college student is associated with less effective acquisition and deployment of cultural capital throughout the research process (Grineski et al., 2018). The researchers hypothesized that first-generation students may not ask the "right" questions needed to develop capital in research; they also proposed that firstgeneration students may feel uncomfortable asking for help, which may hinder them from accruing additional capital in the research environment. Finally, Gazley et al. (2014) explored the cultural capital, specifically institutional cultural capital and embodied cultural capital garnered by students in a postbaccalaureate program. Some students in the study discussed garnering institutional cultural capital through research in the form of letters of recommendation, while others described wanting to engage in research to develop embodied cultural capital because they were worried that they would not be perceived as the type of student to be accepted into a highly competitive program. While these studies demonstrate that students' capital, particularly social and cultural capital, affect students' experiences in research, to our knowledge no studies have explicitly explored whether there are differences in capital between students who obtain an undergraduate research experience and those who want to do undergraduate research but have not successfully obtained research positions.

\section{Scientific research capital}

We propose the novel construct of "scientific research capital," or the economic, social, and cultural capital that influence students' paths to engaging in undergraduate research, as well as how students can succeed in their experiences in undergraduate research (Fig. 2). Scientific research capital is field-specific. That is, it is specific to, or advantageous within, a specific field (science) within a university environment and offers benefits to the potential careers of undergraduate students. Because the type of capital required for entering undergraduate research experiences is not well studied, we can only hypothesize about the types of capital required to access research positions. We draw from existing research about the types of capital required to maximize an undergraduate's research experience in the construction of this idea of a novel type of research-focused science capital.

\section{Scientific research capital: economic capital}

Undergraduate research labs may require students to volunteer before they are able to be paid for their time; thus, students who have more economic capital and can afford to spend their time volunteering are probably more likely to pursue a research position than students who have to spend their extra time outside of school working a job (Cooper, Gin, Akeeh, et al., 2019; Miller, 


\section{Scientific Research Capital}

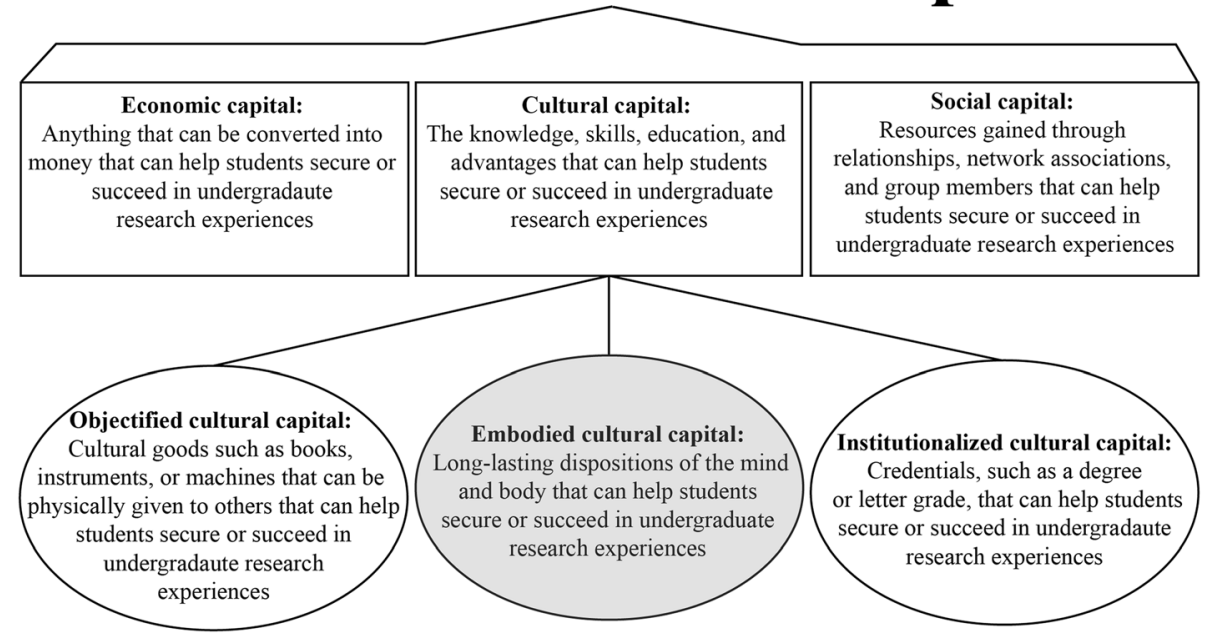

Fig. 2 Scientific research capital describes capital that influence students' paths to engaging in undergraduate research, as well as how students can succeed in their experiences in undergraduate research. It is comprised of economic, cultural, and social capital as described in the squares. There are three types of cultural capital—objectified, embodied, and institutionalized—as described in the circles. The focus of this study, embodied cultural capital, is shaded

Hamel, Holmes, Helmey-Hartman, \& Lopatto, 2013). Further, some schools exchange course credit for participating in research (Cooper, Gin, Akeeh, et al., 2019). This also may favor students with greater economic capital if students have to pay for additional credit to participate in research, if this additional course credit interferes with the time needed for them to have a paying job, or if this lengthens the amount of time that they take to complete their degree because they are doing research as opposed to completing other necessary courses. Once students obtain a research position, economic capital partially governs which students persist in research. Specifically, a national study of 768 undergraduate researchers from 25 public US researchintensive (R1) institutions found that over a quarter of students reported that they considered leaving their undergraduate research experience because they needed to spend time making money instead of doing research (Cooper, Gin, Akeeh, et al., 2019). Presumably, finances also limit the amount of concentrated time that students can spend in research each week; students with more economic capital, in the form of more financial support, may be able to contribute more hours to undergraduate research experiences than those with less financial support. In both cases, students with greater economic capital would likely reap additional benefits from research compared to their counterparts with less capital, since studies have shown that the more time a student spends in research, the more benefits they gain (Adedokun et al., 2014; Daniels et al., 2016; Prunuske, Wilson, Walls, \& Clarke, 2013; Russell et al., 2015; Thiry \&
Laursen, 2011). In fact, undergraduates from lowereconomic backgrounds have been shown to publish less than their peers from higher economic backgrounds (Grineski et al., 2018).

\section{Scientific research capital: social capital}

Undergraduates, graduate students, and faculty can play an important role in exposing students to what undergraduate research is and notifying students of research opportunities (Ashley, Cooper, Cala, \& Brownell, 2017; Cooper, Gin, \& Brownell, 2019; Thompson et al., 2016). Faculty members can recommend students to a research position or they can write a letter of recommendation or serve as a reference, which may be required for certain types of undergraduate research programs (Thompson et al., 2016). Graduate student teaching assistants can recruit students to work with them on their research or can connect them to other graduate students who may want to recruit an undergraduate. Undergraduates can also advertise research opportunities to their friends. Students who participate in clubs or bridge programs that value undergraduate research may have increased access to these individuals who can connect them with research-related opportunities (Cooper, Ashley, \& Brownell, 2018). We hypothesize that students who develop social capital by forming relationships with undergraduates, postgraduates, and faculty are more likely to know about undergraduate research, realize the benefits of undergraduate research, and ultimately participate in undergraduate research. Further, students with stronger social ties may be better able to advocate for what they 
need in order to be successful in undergraduate research (Pfeifer, Reiter, Hendrickson, \& Stanton, 2020). Once students obtain research experiences, they can leverage their relationships with other undergraduates, postgraduates, and faculty to obtain benefits, such as publications, and such relationships will likely foster other benefits, such as gains in students' abilities to think and work like scientists, their research self-efficacy, their science identity, and their career preparation (Aikens et al., 2016; Morales, Grineski, \& Collins, 2017; Thompson et al., 2016).

\section{Scientific research capital: cultural capital}

Students enter their undergraduate careers with knowledge and skills that help them navigate their college experience (Conley, 2007; Hooker \& Brand, 2010); some students will have greater cultural capital that aligns with what is needed to succeed. We hypothesize that students who possess embodied cultural capital related to scientific research are more likely to obtain undergraduate research experiences. Students have to be aware of what research is and know that scientific research is different from what they might have considered research to be for a class project. They have to know that even though research is not part of most standard undergraduate science curricula, it is an activity that is recommended for every undergraduate science major and that they should seek it out (American Association for the Advancement of Science, 2011; National Research Council, 2003, 2012; Olson \& Riordan, 2012). Students need to be able to find research experiences; it is likely important that students know how to access and use university resources such as databases of potential research opportunities, how to craft professional emails, and how to learn the basic information about the type of research conducted in a faculty member's lab before meeting with potential mentors (Georgia Institute of Technology, 2019; Wang, 2019). Once students enter a research experience, a different set of knowledge and skills may be valuable. For example, students who know to spend a greater amount of time in the lab, seek successful role models, emulate role model behaviors, know how to manage their time well, and take initiative may gain more benefits from undergraduate research compared to their peers who do not adopt such behaviors (Hunter, Laursen, \& Seymour, 2007; Thompson et al., 2016; Wenderholm, 2004). Further, students may benefit from institutionalized capital, such as a prestigious research award that others in their field will recognize, which will help them advance in their field, or objectified capital such as access to expensive equipment that will help further their research goals.

\section{The tacit or unwritten nature of scientific research cultural capital}

While there is some evidence to suggest that students with more economic and social capital may be more likely to secure research experiences (Aikens et al., 2016; Cooper, Gin, \& Brownell, 2019; Thompson et al., 2016), there is little known about what specific embodied cultural capital, or what specific information, predicts which students get to participate in undergraduate research. Embodied cultural capital is often implicit in that it is not written down and thus, not easy to transfer. For example, Bourdieu explains cultural capital as tacit adherence to the "rules of the game" that is learned from consistent exposure to a particular culture, such as the culture of academic science (Bourdieu, 1991). Applied to undergraduate research, this would suggest that some students arrive at college knowing how to find and secure research positions, especially if they were exposed to an academic culture growing up (for example, if their parents were academics or if the culture of their high school aligned with the culture of college). If access to such knowledge would broaden and likely diversify who gets to participate in science, specifically scientific research, why is such knowledge not made more available to all students? Bourdieu posited that in the field of science, only a small number of individuals garner enough cultural capital, or skills and knowledge, that allow them to hold places of power in the academic scientific community (Bourdieu, 1991). If such knowledge were widely distributed, it would likely dismantle the academic power structure; privileged individuals who normally rise to hold positions of power because their culture aligns with the academic culture would no longer have the advantage. Therefore, individuals with the most capital may be inspired to keep the cultural capital unwritten to ensure their status. Additionally, cultural capital may be unwritten because it is situational; for example, the knowledge about what to do in a specific situation may not apply to a similar situation at a later point in time. Finally, cultural capital may be unethical; the knowledge about how to get ahead or advance in a particular field may be morally suspicious or corrupt and thus individuals may be even more inclined to keep such knowledge hidden or only pass on this information to someone that they trust not to advertise it more broadly. For example, this could range from feigning interest in a specific research topic to exaggerating about proficiency or prior experience with a particular technique to actively concealing one's intention in going to medical school because faculty members may prefer to train someone interested in pursuing a career in research. In sum, embodied cultural capital may be especially difficult for undergraduates to obtain because of its tacit nature. Documenting the "rules of the game" related to 
obtaining an undergraduate research experience may help undergraduates understand what is necessary to secure such a position.

\section{Current study and context}

The aim of this study is to examine scientific research cultural capital: what embodied cultural capital is necessary to obtain a biology undergraduate research position at a large research-intensive institution in the US? We set out to begin to examine scientific research embodied cultural capital by articulating information or so-called rules that are known to students who secure undergraduate research positions, but that may not be known by students who want to participate in undergraduate research but have not obtained a research position. We took an approach of intentionally collecting data from one institution to establish the rules at that university; it is possible that the rules may be different at different institutions, so we wanted to constrain the variation by focusing on a single institution. While we predict that these rules would be generally similar across multiple institutions, we acknowledge that institutional cultural differences may impact the importance of certain rules. We conducted in-depth, semi-structured interviews with students who were participating in undergraduate research and students who were not participating in undergraduate research but wanted to. We identified some of the knowledge necessary to "play the game" of finding and securing an undergraduate research experience at a large public R1 institution. We chose to refer to this set of knowledge that is scientific research cultural capital as rules of research to streamline our language throughout the article. We predict that there are additional rules of research related to fully maximizing a student's research experience that are not addressed within this study, so we present these rules as a starting point rather than an exhaustive list. To identify what knowledge about participating in an undergraduate research experience was unknown to students who were not involved in undergraduate research, we compared the rules of research that were described by undergraduate researchers to the rules of research that were described by students who wanted to do research but had not successfully obtained a position to see if there were any differences. This study illustrates that scientific research embodied cultural capital may be a previously unexplored factor influencing who gets to participate in undergraduate research.

\section{Methods}

In this study, we took a mixed-methods approach to identify scientific research embodied cultural capital. We used qualitative analysis to identify potential rules of research and then used quantitative analysis, facilitated by the large number of student interviews $(n=85)$, to identify whether there were differences in which rules were known by researchers and non-researchers.

\section{Student interviews}

In spring 2016, spring 2017, and spring 2018, we recruited students for interviews from lower- and upperdivision biology courses at a large research-intensive (R1) institution in the Southwest US. We chose to conduct this study at an R1 institution because of the large number of students who engage in undergraduate research in faculty member labs at these types of institutions and because of how competitive getting into research can be at these types of institutions; studies have shown that a smaller percent of students participate in research at R1 institutions compared to students at undergraduate-focused institutions ( $\mathrm{Hu}, \mathrm{Kuh}$, \& Gayles, 2007; Mahatmya et al., 2017).

We sent emails to students inviting them to provide us with feedback about their experience in the biology department in exchange for a \$15 gift card. Our recruitment materials specified that we were interested in talking with students who either were involved in undergraduate research or were interested in becoming involved in undergraduate research; both groups of students had the motivation to participate in undergraduate research. We aimed to recruit a relatively similar number of students who were involved in research (referred to as researchers from here forward) and students who were interested in becoming involved in research and who were actively looking for research but who were not involved (referred to as non-researchers from here forward). In total, 85 students, 43 researchers and 42 nonresearchers, agreed and were eligible to participate in the study.

We developed an interview script to identify the rules of undergraduate research. Specifically, we focused on two points in a student's process of obtaining a research experience: finding research opportunities and securing a research position (Fig. 3). We conducted a series of think-aloud interviews with six undergraduate researchers and six non-researchers in order to establish cognitive validity of the interview questions before we started the interviews with these participants (Trenor, Miller, \& Gipson, 2011). We iteratively revised the interview questions until no questions were misinterpreted by students. We asked students how they had found or how they would find an undergraduate research experience, and how they had previously secured or would secure an undergraduate research experience (See Supplemental Material for student interview scripts).

Interviews were individually conducted by three researchers. The researchers conducted the think-aloud interviews as a group to ensure that their interviewing techniques were as similar as possible. They also listened 


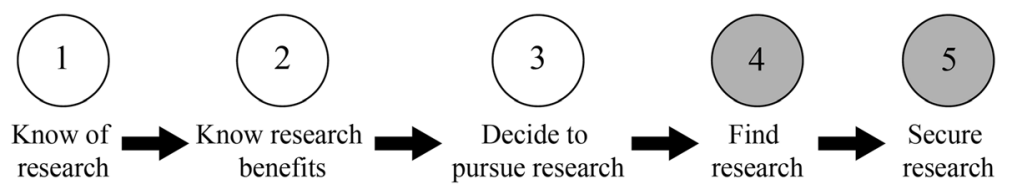

Fig. 3 Points along the process of obtaining an undergraduate research experience where we aimed to identify the rules of research

to each other's recordings and discussed the interviews to help recalibrate their interviewing approach throughout the interview process. Each interview lasted approximately 1 hour. At the end of the interview, students completed a short demographic survey. Interviews were transcribed and pseudonyms were given to students to protect their identity.

\section{Student interview analysis}

All three authors began by identifying the rules of research or strategies that students described using or that they would use in order to find and secure an undergraduate research opportunity. We individually reviewed a set of the same four interviews and then came together to discuss themes or rules we had identified. Together, we used constant comparison methods (Glesne \& Peshkin, 1992) to create a coding rubric that described each rule that we had identified (See Table S1 for a copy of the coding rubric). Specifically, we constantly compared quotes within each theme to ensure that the student quotes were not different enough from each other to warrant the creation of another rule. This process was repeated until no new themes were emerging and we were confident that saturation had been reached (Guest, Bunce, \& Johnson, 2006). All rules of research were identified when reviewing the first twelve interviews of researchers. However, we continued to interview more students, both researchers and non-researchers, to allow for the quantitative analyses. In total, each person reviewed $26(31 \%)$ of the interviews. Two of the authors (KMC and JMC) used the rubric to independently code 17 of the interviews (20\% of all interviews) and their Cohen's kappa interrater score was at an acceptable level $(\kappa=.80)$ (Landis \& Koch, 1977). Then, one coder (JMC) coded the remaining transcripts using the rubric. We report out all the rules that we identified that were mentioned by at least $15 \%$ of all students.

\section{Quantitative analyses}

We used logistic regression to test whether researchers were more likely than non-researchers to mention any of the rules of research. To ensure that any differences in knowledge of the rules between the two groups were not accounted for by other factors, we controlled for student gender, race/ethnicity, college generation status, whether a student had transferred to the institution from a community college, grade level, and grade point average (GPA) in the model. For each rule of research, we ran the model: identified rule in the interview $(\mathrm{Y} / \mathrm{N}) \sim$ researcher/non-researcher + gender $^{1}$ (man/woman) + race/ethnicity ${ }^{2}$ (non-PEER/PEER) + college generation status (non-first gen/first gen) + transfer status (transfer student/non-transfer student) + grade level ${ }^{3}$ (upperlevel/lower-level) + GPA. Because we ran 10 regressions, a $\mathrm{BH}$ adjustment at the 0.05 false discovery rate level was applied to the results (Benjamini \& Hochberg, 1995; Glickman, Rao, \& Schultz, 2014). The full results of the logistic regressions can be found in Table S2.

\section{Results}

Undergraduate researchers and non-researchers

Of the 85 students who participated in the interviews, 43 students were currently participating in an undergraduate research experience and 42 wanted to participate in research but were not. A summary of the demographics of researchers and non-researchers are presented in Table 1.

\section{Student interviews revealed 10 rules of research, four of which were more likely to be identified by researchers than non-researchers}

From the student interviews, we identified 10 rules of research or student-reported factors that were important for finding research and securing research.

\section{Finding research}

Students commonly described five ways to find a research position. Students suggested using online

\footnotetext{
${ }^{1}$ We recognize that not all students identify as gender binary (man or woman) (Cooper et al., 2020); however, there were too few students who identified as non-gender binary to include this category in the analysis.

${ }^{2}$ We collapsed students who identify as Black or African American, Hispanic, Latino/a or of Spanish Origin, and American Indian or Alaska Native into one category, which we call Persons Excluded because of their Ethnicity or Race (PEER) (Asai, 2020). These students share the experience of being underserved by institutions of higher education; we recognize that the experiences of these students are different, but the small sample sizes necessitated that we pool these identities as a single factor in our analyses.

${ }^{3}$ We grouped students by grade level, students who were in their first 2 years of college were grouped as "lower-level" and students who were in at least their third year of college of more were grouped as "upperlevel."
} 
Table 1 Demographics of researchers and non-researchers who participated in the interviews

\begin{tabular}{lll}
\hline Demographic & $\begin{array}{l}\text { Non-researchers, } \\
\boldsymbol{n}=\mathbf{4 2} \\
\text { \% }\end{array}$ & $\begin{array}{l}\text { Researchers, } \\
\boldsymbol{n}=\mathbf{4 3}\end{array}$ \\
& $\mathbf{\%}$
\end{tabular}

university resources (reported by $84 \%$ of students). Sixty-eight percent of students said that one can find out about research positions by talking with instructors, 29\% of students mentioned talking with academic advisors, $21 \%$ suggested talking with graduate teaching assistants, and $21 \%$ suggested talking with peers about potential research opportunities. See Table 2 for a description of each rule of research and example quotes from researchers and non-researchers.

\section{Securing research}

Students reported what they would do or what they did do in order to secure a research position. Students highlighted that it was important to express interest in a research position, regardless of students' actual interest in the research topic (reported by $60 \%$ of interviewees).
Forty-two percent of students also described that in order to secure a research position, one should do research to learn more about the faculty member's lab and the type of research they do before writing an initial email or interviewing for the position and 39\% of students recommended building a relationship with the primary investigator to increase their chances of being accepted to a lab. Finally, 33\% of students explained that it is important to be engaged during an interview for a research position and $27 \%$ of students highlighted the importance of emailing multiple PIs about research opportunities, since securing a research position is competitive. See Table 2 for a description of each rule of research and example quotes from researchers and nonresearchers.

We tested whether researchers were more likely to know specific rules than non-researchers. The nature of the open-ended interviews did not limit the number of rules a student could mention and we did not specifically ask students about any rule. Therefore, it is possible that a student who knows of a particular rule would not think to mention it and we are underestimating the rules that they know. However, we hypothesized that the students who secured research positions likely had more embodied scientific research cultural capital than students who wanted to participate in research but were not. Controlling for students' gender, race/ethnicity, college generation status, transfer status, year in college, and GPA, we identified four rules that were significantly more likely to be known by researchers than nonresearchers. All four rules that were more likely to be known by researchers than non-researchers were specific to securing a research experience. Specifically, researchers were more likely than non-researchers to explain that in order to secure a research experience, students should express interest in the research experience, do background research on the lab and research conducted in the lab, be engaged during the interview, and email multiple PIs at the same time about pursuing a research position in their lab. The full results of each regression testing to what extent researchers were more likely than non-researchers to know a particular rule are reported in the Supplemental Material and the $p$ values associated with whether researchers were more likely to know each rule, which were adjusted using a BH correction for false discovery rate at the 0.05 level, are reported in Table 3.

In sum, from our interviews, we identified 10 rules of research, or strategies that may help students find and secure undergraduate research positions (Fig. 4). We found that four of the rules were more likely to be known by researchers than non-researchers; all of the rules that non-researchers were less likely to know had to do with securing research. Therefore, knowledge of 
Table 2 Each rule of research described by interviewees about how to find a research experience and how to secure a research experience

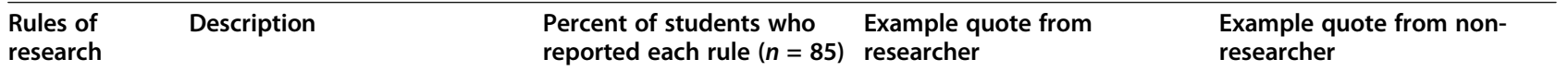

\section{Finding research}

Use online Students can use university university online resources (e.g., faculty resources websites, databases to search university research positions) to find research opportunities.
Talk with instructors

Students can talk with instructors about research opportunities in their lab or in other labs on campus.
Talk with advisors

Talk with graduate students

Talk with peers academic advisors about at the university.

Students can talk with graduate teaching assistants about how to find available research opportunities.

Students can talk with their peers about whether they know of any ways to find undergraduate research experiences at their institution.
Students can talk with research opportunities that exist
$84 \%$

o

eported each rule $(n=85)$

Googled lresearch

"I Googled [research opportunities]. I wasn't really informed about it, I just wanted to do research so I went out of my way to look for it. (...)। went on [the college website] and each PI has their own website so I went into those and read about their research."-Sofia

"For certain positions, I've had to go and ask professors, 'Are you doing anything right now? Can I get involved with you?" Rene

$\%$

\section{Securing research}

Express interest

When sending an email or during an interview, expressing interest in the research position can increase a student's odds of securing the research position.
Do background
Doing background research on a lab and the specific research
"I let [the PI] know that I did know what they did, and I was actually interested in what they were doing and that I didn't just pull their name out of the [Biology Department] website and be like, 'Oh I want to research with you.' I wanted to make sure that I was actually interested in anything that I'd be getting myself into and I wouldn't want to find out later that I wasn't interested in his things and waste his time if he had emailed me back."-Becca

"A [PI] sent out an email to the [Biology Department] listserv [to
"They have [information] on the [college] website you go to. I don't know what it's called. I looked at it before and there's a ton of different things you can do."-Sarah

"I would probably ask my professors first [about how to find research opportunities]. I would probably ask [Professor $X]$ if she knew anything, because I'm sure she could at least direct me somewhere even if she didn't know of anything."-Emmy

"I think there might be an advisor or somebody who can lead you to research."--Rayna

"I would probably talk to my TAs in my bio class and ask what they have heard about [getting into research] and see what they would direct me to and go from there."-Jamie

“There's people working [in a research lab]. Like other students too. So maybe I might know that student or a friend might know that student, like a connection."-Lee

"I'd just [send an email and] say I'm interested in whatever topic they're researching. I'm a sophomore, I want to be involved. I think l'd be a great student for this research. Just let them know you're interested. And then send it."-Martricia

"I'd look into the lab myself. They usually have websites 
Table 2 Each rule of research described by interviewees about how to find a research experience and how to secure a research experience (Continued)

\begin{tabular}{|c|c|c|c|c|}
\hline $\begin{array}{l}\text { Rules of } \\
\text { research }\end{array}$ & Description & $\begin{array}{l}\text { Percent of students who } \\
\text { reported each rule }(n=85)\end{array}$ & $\begin{array}{l}\text { Example quote from } \\
\text { researcher }\end{array}$ & $\begin{array}{l}\text { Example quote from non- } \\
\text { researcher }\end{array}$ \\
\hline research & $\begin{array}{l}\text { going on in that lab before } \\
\text { sending an email or } \\
\text { interviewing for a position in } \\
\text { the lab can help students } \\
\text { secure a research position. }\end{array}$ & & $\begin{array}{l}\text { fill an open research position] } \\
\text { and I applied for that, telling } \\
\text { them about what I know about } \\
\text { them, the research they've } \\
\text { published, and discussed that } \\
\text { and tried to make connections } \\
\text { between what they had done } \\
\text { research on and what I had } \\
\text { done research on to make me } \\
\text { look more employable."-Logan }\end{array}$ & $\begin{array}{l}\text { about what they're doing, so I } \\
\text { would try to educate myself on } \\
\text { what they're doing and before I } \\
\text { send an email [to the } \mathrm{Pl} \text { ] and } \\
\text { then I'd hope to hear } \\
\text { something back from that } \\
\text { email."-Gabriella }\end{array}$ \\
\hline $\begin{array}{l}\text { Build } \\
\text { relationships } \\
\text { with PIs }\end{array}$ & $\begin{array}{l}\text { Building a relationship with a PI } \\
\text { by exchanging emails, visiting } \\
\text { during office hours, or getting } \\
\text { to know them as an instructor } \\
\text { can increase a student's chance } \\
\text { of joining their lab. }\end{array}$ & $39 \%$ & $\begin{array}{l}\text { "The PI [that I was interested in } \\
\text { working with] happened to be } \\
\text { also my professor for one of my } \\
\text { classes in the fall, so I got to } \\
\text { bug him in person and it } \\
\text { worked better. So I had to talk } \\
\text { to him in person a few times, } \\
\text { and that's how we started."- } \\
\text { Hannah }\end{array}$ & $\begin{array}{l}\text { "Honestly, l'd probably go to my } \\
\text { professors I know [to get a } \\
\text { research experience]. I believe } \\
\text { that would be the best shot. } \\
\text { Especially they might know } \\
\text { something, if you're lucky } \\
\text { enough to have found } \\
\text { someone that does research on } \\
\text { something that you are } \\
\text { interested in, I believe that } \\
\text { would be the best way to go } \\
\text { about doing it because it would } \\
\text { help you go through the } \\
\text { process."-Max }\end{array}$ \\
\hline $\begin{array}{l}\text { Be engaged } \\
\text { during the } \\
\text { interview }\end{array}$ & $\begin{array}{l}\text { During the interview, being } \\
\text { attentive, staying engaged and } \\
\text { asking relevant questions can } \\
\text { improve a student's chances of } \\
\text { securing a research position. }\end{array}$ & $33 \%$ & $\begin{array}{l}\text { "[During the interview] I asked } \\
\text { [the PI] more questions about } \\
\text { his research. Finding out what } \\
\text { he's working on and then as } \\
\text { soon as he said something that } \\
\text { sounded interesting to me, I } \\
\text { commented on it. Just keeping } \\
\text { a bit of a conversation going as } \\
\text { far as the interview went rather } \\
\text { than him just asking me a } \\
\text { question waiting for the next } \\
\text { question."-Madison }\end{array}$ & $\begin{array}{l}\text { "[During the interview, I would } \\
\text { show I'm qualified to do } \\
\text { research by] always asking } \\
\text { questions, showing that you } \\
\text { actually care what you're } \\
\text { learning about instead of just } \\
\text { trying to get through it."- } \\
\text { Brandon }\end{array}$ \\
\hline $\begin{array}{l}\text { Email } \\
\text { multiple PIs }\end{array}$ & $\begin{array}{l}\text { Emailing more than one PI at } \\
\text { the same time when trying to } \\
\text { obtain a research position can } \\
\text { increase a student's chance of } \\
\text { securing a research position. }\end{array}$ & $27 \%$ & $\begin{array}{l}\text { "I just spent like a few days, like, } \\
\text { I literally clicked every faculty's } \\
\text { name and I looked at their } \\
\text { research and then I saved the } \\
\text { ones that I liked. And then I like, } \\
\text { um, I emailed } 6 \text { people initially, } \\
\text { like, I emailed a lot."-Mia }\end{array}$ & $\begin{array}{l}\text { "I figured out [which PIs] would } \\
\text { be a fit and which labs I would } \\
\text { want to get into, then I emailed } \\
\text { them. Like, if I send out ten } \\
\text { emails there's a higher } \\
\text { chance."-Daniel }\end{array}$ \\
\hline
\end{tabular}

scientific research cultural capital may be what separates students who successfully obtain research positions from students who want to do research but have been unsuccessful in obtaining a position.

\section{Discussion}

In this study, we set out to describe one specific aspect of scientific research capital: the embodied cultural capital that would help students secure a scientific undergraduate research experience at one institution. We aimed to explore whether there were differences in embodied cultural capital between researchers, or students who participate in research, and non-researchers, or students who want to participate in research but had not successfully obtained a position. As such, we interviewed researchers and non-researchers regarding what they know about how to find and secure an undergraduate research experience. From these interviews, we established a potential set of rules of research, or the information needed to find and secure an undergraduate research experience.

We argue that the rules of research that are more likely to be known by researchers but unknown by nonresearchers represent important scientific research cultural capital that is currently unevenly distributed to students. That is, knowing this information is helpful to students interested in participating in an undergraduate research opportunity and may separate students who successfully obtain research experiences from those who want to participate but struggle to obtain opportunities. 
Table 3 Percent of non-researchers and researchers who reported each rule during the interview

\begin{tabular}{|c|c|c|c|}
\hline Rules of research & Non-researchers $(n=42)$ & Researchers $(n=43)$ & $p$ value $^{a}$ \\
\hline \multicolumn{4}{|l|}{ Finding research } \\
\hline Use online university resources & $86 \%$ & $81 \%$ & 0.93 \\
\hline Talk with instructors & $67 \%$ & $70 \%$ & 0.63 \\
\hline Talk with advisors & $33 \%$ & $26 \%$ & 0.40 \\
\hline Talk with graduate students & $31 \%$ & $12 \%$ & 0.23 \\
\hline Talk with peers & $14 \%$ & $28 \%$ & 0.21 \\
\hline \multicolumn{4}{|l|}{ Securing research } \\
\hline Express interest ${ }^{\mathrm{b}}$ & $43 \%$ & $77 \%$ & 0.04 \\
\hline Do background research ${ }^{\mathrm{b}}$ & $19 \%$ & $65 \%$ & 0.01 \\
\hline Build relationships with PIs & $31 \%$ & $47 \%$ & 0.23 \\
\hline Be engaged during the interview ${ }^{b}$ & $7 \%$ & $58 \%$ & $<0.01$ \\
\hline Email multiple $\mathrm{Pls}^{\mathrm{b}}$ & $9 \%$ & $44 \%$ & 0.01 \\
\hline
\end{tabular}

${ }^{\text {a All }} p$ values have been corrected using the $\mathrm{BH}$ correction at the 0.05 false discovery rate

${ }^{\mathrm{b}}$ Researchers were statistically more likely to report a rule than non-researchers when controlling for gender, race/ethnicity, college generation status, transfer status, year in college, and GPA

Researchers were significantly more likely to describe four of the five rules about securing research. Specifically, researchers were more likely to describe that it is important to express interest in research in an initial email or interview with a PI and to act engaged during an interview by nodding along, asking questions, and generating conversation with the interviewer. They were also more likely to highlight the importance of doing background research about the research lab and about how finding a research experience is difficult, so it is necessary to email multiple PIs to increase one's chances of finding research.

The rules of research may be part of the hidden curriculum in undergraduate science

We propose that some of these rules of research that we have identified are a part of the hidden curriculum of undergraduate science at this institution. Hidden curriculum refers to information that is made available to some students but not others and that is important for determining student success (Margolis, 2002; Martin, 2010). Researchers have used the lens of hidden curriculum to examine the social functions of higher education; students who have access to the hidden curriculum are more likely to succeed while students who do not are less likely to succeed (Margolis, 2002; Martin, 2010). The hidden curriculum has been defined as values, dispositions, and social and behavioral expectations that were valued by grade school instructors (Kentli, 2009; Margolis, 2002). While the theory of hidden curriculum was first applied to studies in primary and secondary education, later studies aimed to further understand the hidden curriculum of higher education (Astin, 1993;

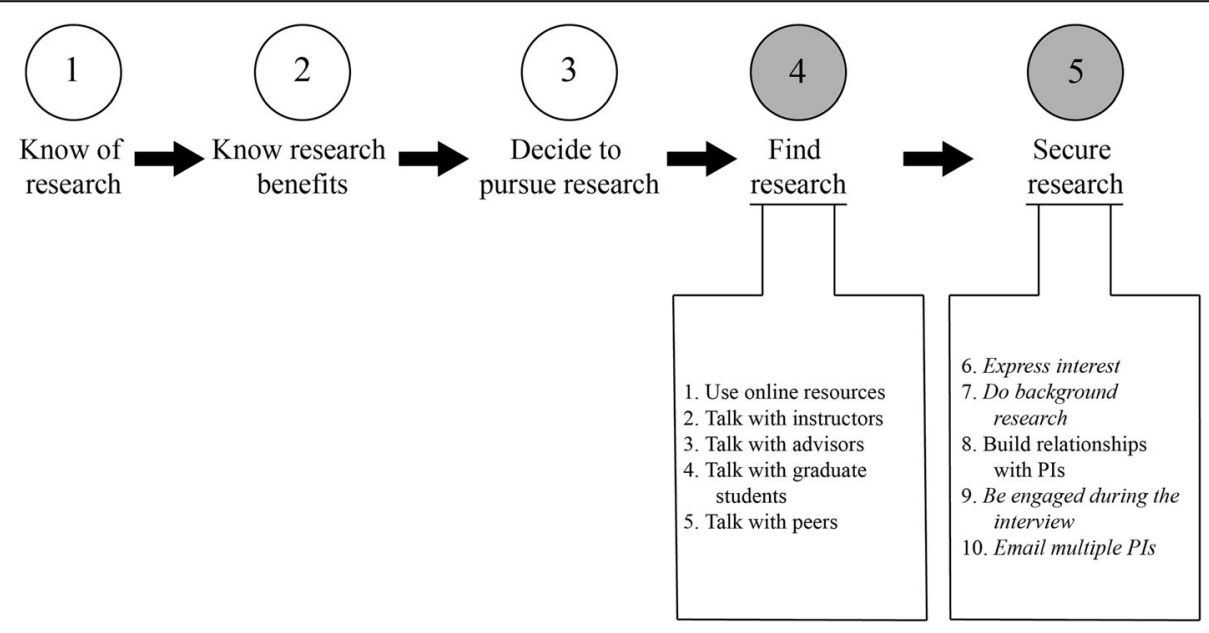

Fig. 4 The rules of undergraduate research 
Bergenhenegouwen, 1987; Margolis \& Romero, 1998). If the rules of research are an important part of the hidden curriculum for undergraduate science students because such knowledge may determine who is successful in obtaining scientific research experiences, should this hidden curriculum be explicitly taught to all undergraduates to level the playing field and create a more inclusive scientific community? Further, an open question is whether these specific rules should be taught to students or if more general strategies to identify the rules should be taught. Those students who become more conversant in demystifying the code can realize advantages and benefits. If general strategies were taught, it would be applicable to a greater number of situations and thus have a larger impact on the success of the student; alternatively, students would have to be taught each rule independently and it may be harder for them to transfer that knowledge to new situations.

\section{Revealing scientific research cultural capital: change the students or change the system?}

One strategy to diversify which students participate in scientific research is to make the hidden curriculum related to undergraduate research more visible. That is, it may be important to unveil the rules of research to all students or help students who want to do research understand that it is important to (1) explicitly express interest in someone's research when contacting them about joining their lab, (2) do background research about the lab they are interested in joining, (3) be engaged in an interview by coming prepared to engage in conversation and ask relevant questions, and (4) reach out to multiple faculty members about joining their lab at the same time since it is difficult to secure a research position. Cultural capital can be learned, although not easily. As such, researchers have proposed that colleges and universities can help students develop cultural capital to advance their positions in science. For example, summer bridge programs and first-year success programs have integrated some of this knowledge into their curriculum with the hope of increasing the number of underrepresented and underserved students who participate in research (Ashley et al., 2017; Cooper et al., 2018). One concern that this approach raises is that if the rules are revealed, new unwritten rules may be created to reinforce the existing hierarchy. That is, if revealing this cultural capital threatens the positions of those in power by leveling the playing field, new subtle rules may emerge. This idea is congruent with the theory of effectively maintained inequality, which suggests that if a particular education level becomes saturated, those from more privileged backgrounds will create or find a competitive edge to maintain their advantage (Lucas, 2001). Additionally, the approach of unveiling the unwritten rules assumes that there is a disconnect between the culture of some students and the upper-middle class, white culture of academia; further, it asserts that underrepresented and underserved students lack the cultural capital necessary to succeed in science (Archer et al., 2015; Ovink \& Veazey, 2011). Researchers have critiqued this view because it reinforces a student deficit model; it assumes that the students need to change in order to conform to the already successful system of academia (Thompson et al., 2016; Yosso, 2005).

Indeed, we agree that the responsibility should be placed on the system to change and not on the student. In order to create sustainable change with regard to who gets to participate in research, we posit that science faculty need to value scientific research cultural capital that does not align with what is traditionally valued by academia (Thompson \& Jensen-Ryan, 2018). We argue that it may be unethical for faculty to rely on the unwritten rules as a way to select students into their lab if such rules are only available to a select, potentially more privileged, group of students. For example, instead of valuing students who take the time to read through lab webpages and learn about research on their own, perhaps faculty members need to be more forthright in telling students to look at their webpages or to not expect students to do so before having them join the lab. Changes in what academics value should result in changes in who is accepted into undergraduate research. An additional systemic solution is to eliminate the need for the rules of research altogether in order to participate in undergraduate research. For example, coursebased undergraduate research experiences (CUREs) embed authentic research experiences in the context of a lab course (Auchincloss et al., 2014; Brownell \& Kloser, 2015) and as such, students may not need to know any information to participate in research, they may simply need to enroll in the course. However, students may still need to know why undergraduate research may be beneficial to them, know what a CURE is, and identify which courses, if any, in their department are CUREs in order to participate. Yet, if CUREs are integrated into the required undergraduate curriculum (Brownell et al., 2015; Cooper, Blattman, Hendrix, \& Brownell, 2019), it could diversify which students participate in undergraduate research by eliminating the need to know any rules of research in order to participate in research (Bangera \& Brownell, 2014). However, we do not know if students currently acquire more cultural capital from traditional undergraduate research experiences than CUREs and this would be an important area of future research. Further, it is important to acknowledge that we do not currently know if graduate schools or medical schools view CUREs as equivalent to traditional undergraduate research experiences, so the perception of these 
research experiences may still contribute to inequities in how students can leverage the experience.

The systemic restructuring of the scientific enterprise will be a lengthy process. Both changing the average faculty mindset and values, and integrating CUREs as required courses, will take significant time and resources. As such, we recognize the need for more immediate solutions. Although teaching the rules to students does adopt a student deficit model, we argue that it is a potentially viable and more immediate way to ensure that students have access to undergraduate research, regardless of their cultural background. Further studies need to be done to determine whether incorporating the rules of research into undergraduate curricula affects which students succeed in obtaining research experiences. We encourage instructors to use the rules that we have identified from students at one institution as a set of guidelines and add any additional rules that they think might be useful to know at their own institutions. These guidelines could be incorporated into student orientation, summer bridge programs, and success courses for first-year students or transfer students.

Additionally, faculty and graduate students can share these unwritten rules with students in more informal settings, such as during office hours. While this is likely already happening, especially given the number of students in our study who said that they found out about research experiences through faculty and graduate students, it is possible that faculty and graduate students are only sharing this information with undergraduates who already have high levels of cultural capital (for example, those who come asking about how to find undergraduate research or those who know to ask faculty specifically about the research that they do). Thompson and Jensen-Ryan (2018) suggested that faculty recognition and cultural capital operate in a positive feedback loop, which can create consequences for students who do not enter undergraduate science disciplines with forms of cultural capital recognized by scientists. That is, faculty are more likely to recognize students who possess cultural capital and facilitate students' access to additional opportunities, such as undergraduate research experiences, which will in turn build additional scientific cultural capital (Thompson \& Jensen-Ryan, 2018). Therefore, faculty and graduate students should consider who they share information with about how to obtain research experiences and consider broadening the network of students with whom they share this information. Although it has been well-documented that firstgeneration students may not know the rules to navigate college as well as continuing generation students (Collier \& Morgan, 2008), the rules of research may be unknown to an even broader population of students. Scientific research embodied cultural capital may also not be known by continuing generation students who do not have parents who are scientists since research is not a concept familiar to everyone who went to college. We propose that faculty and graduate students be generous with sharing scientific research embodied cultural capital and actively be explicit about what they want students to know before pursuing an undergraduate research position.

While we could have taken a more theoretical approach to the "rules" and identify what the conceptual underpinnings of a particular rule might be, we chose to take a more pragmatic approach of identifying the specific rule that students mentioned because this is what faculty members could explicitly say to students. Thus, these 10 rules represent 10 concrete suggestions that faculty members can give students who are interested in an undergraduate research experience. We hope that these rules could have immediate impact on potential undergraduate researchers.

\section{Limitations}

This was an interview study and as such, we were limited in the number of students who participated and we only inquired into their knowledge at a single timepoint when they either were or were not doing research. In future studies, researchers could interview students who just obtained a research position before they participate in the lab to capture their cultural capital at that time and compare it to the cultural capital of nonresearchers. This study design would control for whether students learn any rules of research as a result of participating in research. We were unable to take this approach because students at the institution where we conducted our study join research programs at various times throughout the academic year, and there was no feasible way to identify a student who had just joined a research program. Additionally, when we recruited nonresearchers for this study, we specifically identified individuals who wanted to participate in research but were not currently participating. We did not explicitly ask students whether they had tried to find a research position, although all students referenced trying to find a research position at some point in their interview. Future studies could capture the knowledge of non-researchers who tried to find a research opportunity and compare it to non-researcher who did not try to find a research opportunity; we predict that these students may have differential motivation to find a position.

A limitation to this study design was that we asked students open-ended questions about what they knew with regard to finding and securing undergraduate research experiences. Therefore, it is possible that some students knew about certain rules but did not talk about them in the interview. We are certainly not capturing every rule, but we 
may be missing important rules or underestimating the number of students who know a rule. A quantitative approach where students identify which rules they know would potentially provide a more accurate assessment of which rules students know. A survey study would also allow for a larger sample size and inclusion of additional explanatory variables. However, once a student sees a rule in writing, they may recognize it as true even though they did not know about it prior to reading it in a survey, so that is a limitation of that design. We intended this study to be situated at a single institution and we do not make claims of generalization beyond this institution. Given the paucity of research in this area, we view this work as a critical first step for articulating what comprises scientific research cultural capital; however, we encourage researchers to test whether the rules of research that we found apply at different institutions to build on to this work.

\section{Conclusion}

We specifically identified scientific research embodied cultural capital, or a set of rules of research that undergraduates may need to know in order to find and secure an undergraduate research experience. We tested whether there were differences in researchers' and nonresearchers' knowledge of the rules and found that undergraduate researchers were more likely to know the rules of research related to securing research experiences. Therefore, educating students about how to secure research experiences and encouraging faculty who provide research experiences to re-think the criteria they use to admit students into their lab may be a key step in leveling the playing field for students who are vying for research positions in an effort to create a more diverse and inclusive scientific research community.

\section{Supplementary Information}

The online version contains supplementary material available at https://doi. org/10.1186/s40594-020-00265-w.

Additional file 1: Student interview scripts. Student demographic questions. Table S1. Copy of the coding rubric for all rules of research. Table S2. Results of regressions testing for whether there are differences between researcher and non-researcher knowledge of the rules, controlling for student gender, race/ethnicity, college generation status, transfer status, grade level and GPA.

\section{Abbreviations}

STEM: Science, technology, engineering, and math; R1: Research intensive; US: United States of America

\section{Acknowledgements}

We thank Erin Dolan for guidance on early stages of this project, and the members of the Arizona State University Biology Education Research Lab and particularly Logan Gin and Rachel Scott for their help and review of earlier versions of this manuscript.

\section{Authors' contributions}

K.M.C. and S.E.B. conceptualized the project. K.M.C., J.M.C., and S.E.B. conducted the interviews for the project, analyzed the data, and contributed to the writing of the manuscript. The authors read and approved the final manuscript.

\section{Funding}

We acknowledge the Lincoln Center for Applied Ethics at Arizona State University for funding this project.

\section{Availability of data and materials}

Underlying data are subject to ethical restrictions as the interview transcripts contain identifiable information, including student names and anecdotes that could identify the students. Further, the interviews include sensitive information about students' and students were assured before their interview that their transcripts would never be shared with anyone outside of the research team. It is for these reasons that the data will not be shared. However, the interview protocol is available in the Additional Information.

\section{Competing interests}

There are no competing interests to declare.

\section{Author details}

${ }^{1}$ Research for Inclusive STEM Education Center, School of Life Sciences, Arizona State University, 451 E. Tyler Mall, Tempe, AZ 85281, USA. ${ }^{2}$ Biological Sciences Division, Chandler-Gilbert Community College, 2626 E. Pecos Rd., Chandler, AZ 85225, USA. ${ }^{3}$ Biology Education Research Lab, Research for Inclusive STEM Education Center, School of Life Sciences, Arizona State University, 451 E. Tyler Mall, Tempe, AZ 85281, USA.

Received: 25 March 2020 Accepted: 13 December 2020

Published online: 15 February 2021

\section{References}

Adedokun, O. A., Parker, L. C., Childress, A., Burgess, W., Adams, R., Agnew, C. R., ... Lelievre, S. (2014). Effect of time on perceived gains from an undergraduate research program. CBE Life Sciences Education, 13(1), 139-148.

Aikens, M. L., Sadselia, S., Watkins, K., Evans, M., Eby, L. T., \& Dolan, E. L. (2016). A social capital perspective on the mentoring of undergraduate life science researchers: An empirical study of undergraduate-postgraduate-faculty triads. CBE Life Sciences Education, 15(2), ar16.

Albert, M., \& Kleinman, D. L. (2011). Bringing Pierre Bourdieu to science and technology studies. Minerva, 49(3), 263.

American Association for the Advancement of Science (2011). Vision and change in undergraduate biology education: A call to action http://visionandchange. org/files/2013/11/aaas-VISchange-web1113.pdf.

Archer, L., Dawson, E., DeWitt, J., Seakins, A., \& Wong, B. (2015). "Science capital": A conceptual, methodological, and empirical argument for extending bourdieusian notions of capital beyond the arts. Journal of Research in Science Teaching, 52(7), 922-948.

Archer, L., DeWitt, J., \& Willis, B. (2014). Adolescent boys' science aspirations: Masculinity, capital, and power. Journal of Research in Science Teaching, 51(1), $1-30$.

Asai, D. J. (2020). Race matters. Cell, 181(4), 754-757.

Ashley, M., Cooper, K. M., Cala, J. M., \& Brownell, S. E. (2017). Building better bridges into STEM: A synthesis of 25 years of literature on STEM summer bridge programs. CBE Life Sciences Education, 16(4), es3. https://doi.org/10. 1187/cbe.17-05-0085.

Astin, A. W. (1993). Diversity and multiculturalism on the campus: How are students affected? Change: The Magazine of Higher Learning, 25(2), 44-49.

Auchincloss, L. C., Laursen, S. L., Branchaw, J. L., Eagan, K., Graham, M., Hanauer, D. I., Gwendolyn, L., McLinn, C. M., Pelaez, N., Rowland, S., Towns, M., Trautmann, N. M., Varma-Nelson, P., Weston, T. J., \& Dolan, E. L. (2014). Assessment of course-based undergraduate research experiences: A meeting report. CBE Life Sciences Education, 13(1), 29-40. https://doi.org/10.1187/cbe.14-01-0004.

Bangera, G., \& Brownell, S. E. (2014). Course-based undergraduate research experiences can make scientific research more inclusive. CBE Life Sciences Education, 13(4), 602-606.

Benjamini, Y., \& Hochberg, Y. (1995). Controlling the false discovery rate: A practical and powerful approach to multiple testing. Journal of the Royal Statistical Society: Series B: Methodological, 57(1), 289-300. 
Bergenhenegouwen, G. (1987). Hidden curriculum in the university. Higher Education, 16(5), 535-543.

Bourdieu, P. (1977). Outline of a theory of practice (Vol. 16). Cambridge: Cambridge University Press.

Bourdieu, P. (1986). The forms of capital. In J. Richardson (Ed.), Handbook of theory and research for the sociology of education içinde, (pp. 241-258). New York: Greenwood Press.

Bourdieu, P. (1991). The peculiar history of scientific reason. Sociological Forum, 6, $3-26$.

Brownell, S. E., Hekmat-Scafe, D. S., Singla, V., Chandler Seawell, P., Conklin Imam, J. F., Eddy, S. L., ... Cyert, M. S. (2015). A high-enrollment course-based undergraduate research experience improves student conceptions of scientific thinking and ability to interpret data. CBE Life Sciences Education, 14(2), ar21.

Brownell, S. E., \& Kloser, M. J. (2015). Toward a conceptual framework for measuring the effectiveness of course-based undergraduate research experiences in undergraduate biology. Studies in Higher Education, 40(3), 525-544. https://doi.org/10.1080/03075079.2015.1004234.

Carter, F. D., Mandell, M., \& Maton, K. I. (2009). The influence of on-campus, academic year undergraduate research on STEM Ph. D. Outcomes: Evidence from the Meyerhoff scholarship program. Educational Evaluation and Policy Analysis, 31(4), 441-462.

Ceyhan, G. D., \& Tillotson, J. W. (2020). Early year undergraduate researchers' reflections on the values and perceived costs of their research experience. International Journal of STEM Education, 7(1), 1-19.

Collier, P. J., \& Morgan, D. L. (2008). "Is that paper really due today?": Differences in first-generation and traditional college students' understandings of faculty expectations. Higher Education, 55(4), 425-446.

Conley, D. T. (2007). Redefining college readiness. Eugene, OR: Educational Policy Improvement Center (NJ1).

Cooper, K. M., Ashley, M., \& Brownell, S. E. (2017). Using expectancy value theory as a framework to reduce student resistance to active learning: A proof of concept. Journal of Microbiology \& Biology Education, 18(2). https://doi.org/10. 1128/jmbe.v18i2.1289

Cooper, K. M., Ashley, M., \& Brownell, S. E. (2018). Breaking down barriers: A bridge program helps first-year biology students connect with faculty. Journal of College Science Teaching, 47(4), 60-70.

Cooper, K. M., Auerbach, A. J. J., Bader, J. D., Beadles-Bohling, A. S., Brashears, J. A., Cline, E., ... Fuselier, L. (2020). Fourteen recommendations to create a more inclusive environment for LGBTQ+ individuals in academic biology. CBE Life Sciences Education, 19(3), es6.

Cooper, K. M., Blattman, J. N., Hendrix, T., \& Brownell, S. E. (2019). The impact of broadly relevant novel discoveries on student project ownership in a traditional lab course turned CURE. CBE Life Sciences Education, 18(4), ar57.

Cooper, K. M., Gin, L. E., Akeeh, B., Clark, C. E., Hunter, J. S., Roderick, T. B., ... Brownell, S. E. (2019). Factors that predict life sciences student persistence in undergraduate research experiences. PLoS One, 14(8), e0220186. https://doi. org/10.1371/journal.pone.0220186.

Cooper, K. M., Gin, L. E., \& Brownell, S. E. (2019). Diagnosing differences in what introductory biology students in a fully online and an in-person biology degree program know and do regarding medical school admission. Advances in Physiology Education, 43(2), 221-232.

Daniels, H., Grineski, S. E., Collins, T. W., Morales, D. X., Morera, O., \& Echegoyen, L. (2016). Factors influencing student gains from undergraduate research experiences at a Hispanic-serving institution. CBE Life Sciences Education, 15(3), ar30.

DeWitt, J., Archer, L., \& Mau, A. (2016). Dimensions of science capital: Exploring its potential for understanding students' science participation. International Journal of Science Education, 38(16), 2431-2449.

Eagan Jr., M. K., Hurtado, S., Chang, M. J., Garcia, G. A., Herrera, F. A., \& Garibay, J. C. (2013). Making a difference in science education: The impact of undergraduate research programs. American Educational Research Journal, 50(4), 683-713.

Edgerton, J. D., \& Roberts, L. W. (2014). Cultural capital or habitus? Bourdieu and beyond in the explanation of enduring educational inequality. Theory and Research in Education, 12(2), 193-220.

Espinosa, L. (2011). Pipelines and pathways: Women of color in undergraduate STEM majors and the college experiences that contribute to persistence. Harvard Educational Review, 81(2), 209-241.

Gazley, J. L., Remich, R., Naffziger-Hirsch, M. E., Keller, J., Campbell, P. B., \& McGee, R. (2014). Beyond preparation: Identity, cultural capital, and readiness for graduate school in the biomedical sciences. Journal of Research in Science Teaching, 51(8), 1021-1048.

Georgia Institute of Technology (2019). 10 steps to get involved | undergraduate research opportunities program http://www.undergradresearch.gatech.edu/ get-involved.

Glesne, C., \& Peshkin, A. (1992). Becoming qualitative researchers: An introduction. London: Longman.

Glickman, M. E., Rao, S. R., \& Schultz, M. R. (2014). False discovery rate control is a recommended alternative to Bonferroni-type adjustments in health studies. Journal of Clinical Epidemiology, 67(8), 850-857.

Grineski, S., Daniels, H., Collins, T., Morales, D. X., Frederick, A., \& Garcia, M. (2018). The conundrum of social class: Disparities in publishing among STEM students in undergraduate research programs at a Hispanic majority institution. Science Education, 102(2), 283-303.

Guest, G., Bunce, A., \& Johnson, L. (2006). How many interviews are enough? An experiment with data saturation and variability. Field Methods, 18(1), 59-82.

Hathaway, R. S., Nagda, B. A., \& Gregerman, S. R. (2002). The relationship of undergraduate research participation to graduate and professional education pursuit: An empirical study. Journal of College Student Development, 43(5), 614-631.

Hernandez, P. R., Woodcock, A., Estrada, M., \& Schultz, P. W. (2018). Undergraduate research experiences broaden diversity in the scientific workforce. BioScience, 68(3), 204-211.

Hooker, S., \& Brand, B. (2010). College knowledge: A critical component of college and career readiness. New Directions for Youth Development, 2010(127), 75-85.

Hu, S., Kuh, G. D., \& Gayles, J. G. (2007). Engaging undergraduate students in research activities: Are research universities doing a better job? Innovative Higher Education, 32(3), 167-177.

Hunter, A.-B., Laursen, S. L., \& Seymour, E. (2007). Becoming a scientist: The role of undergraduate research in students' cognitive, personal, and professional development. Science Education, 91(1), 36-74.

Huss, M. T., Randall, B. A., Patry, M., Davis, S. F., \& Hansen, D. J. (2002). Factors influencing self-rated preparedness for graduate school: A survey of graduate students. Teaching of Psychology, 29(4), 275-281.

Ishiyama, J. (2002). Does early participation in undergraduate research benefit social science and humanities students? College Student Journal, 36(3), 381-387.

Jones, M. T., Barlow, A. E., \& Villarejo, M. (2010). Importance of undergraduate research for minority persistence and achievement in biology. The Journal of Higher Education, 81(1), 82-115.

Kentli, F. D. (2009). Comparison of hidden curriculum theories. European Journal of Educational Studies, 1(2), 83-88.

Landis, J. R., \& Koch, G. G. (1977). An application of hierarchical kappa-type statistics in the assessment of majority agreement among multiple observers. Biometrics, 33(2), 363-374.

Lareau, A., \& Horvat, E. M. (1999). Moments of social inclusion and exclusion race, class, and cultural capital in family-school relationships. Sociology of Education, 72(1), 37-53.

Lopatto, D. (2004). Survey of undergraduate research experiences (SURE): First findings. Cell Biology Education, 3(4), 270-277.

Lopatto, D. (2007). Undergraduate research experiences support science career decisions and active learning. CBE Life Sciences Education, 6(4), 297-306.

Lucas, S. R. (2001). Effectively maintained inequality: Education transitions, track mobility, and social background effects. American Journal of Sociology, 106(6), 1642-1690.

Mahatmya, D., Morrison, J., Jones, R. M., Garner, P. W., Davis, S. N., Manske, J., ... Ditty, J. (2017). Pathways to undergraduate research experiences: A multiinstitutional study. Innovative Higher Education, 42(5-6), 491-504.

Margolis, E. (2002). The hidden curriculum in higher education. London: Routledge.

Margolis, E., \& Romero, M. (1998). "The department is very male, very white, very old, and very conservative": The functioning of the hidden curriculum in graduate sociology departments. Harvard Educational Review, 68(1), 1-33.

Martin, R. A. (2010). The psychology of humor: An integrative approach. Amsterdam: Elsevier.

Marx, K. (1999). Capital: A new abridgement. Oxford: Oxford University Press.

Marx, K., \& Engels, F. (1942). Wage-labour and capital. New York: International Publishers.

Miller, C. W., Hamel, J., Holmes, K. D., Helmey-Hartman, W. L., \& Lopatto, D. (2013). Extending your research team: Learning benefits when a laboratory partners with a classroom. BioScience, 63(9), 754-762. 
Morales, D. X., Grineski, S. E., \& Collins, T. W. (2017). Increasing research productivity in undergraduate research experiences: Exploring predictors of collaborative faculty-student publications. CBE Life Sciences Education, 16(3), ar42.

National Research Council (2003). BIO2010: Transforming undergraduate education for future research biologists. Washington, D.C.: National Academies Press.

National Research Council (2012). Discipline-based education research understanding and improving learning in undergraduate science and engineering. National Academies Press https://www.nap.edu/catalog/13362/ discipline-based-education-research-understanding-and-improving-learningin-undergraduate.

Olson, S., \& Riordan, D. G. (2012). Engage to excel: Producing one million additional college graduates with degrees in science, technology, engineering, and mathematics Report to the President. Executive Office of the President.

Ovink, S. M., \& Veazey, B. D. (2011). More than "getting us through:" a case study in cultural capital enrichment of underrepresented minority undergraduates. Research in Higher Education, 52(4), 370-394.

Pfeifer, M. A., Reiter, E. M., Hendrickson, M., \& Stanton, J. D. (2020). Speaking up: A model of self-advocacy for STEM undergraduates with ADHD and/or specific learning disabilities. International Journal of STEM Education, 7(1), 1-21.

Prunuske, A. J., Wilson, J., Walls, M., \& Clarke, B. (2013). Experiences of mentors training underrepresented undergraduates in the research laboratory. CBE Life Sciences Education, 12(3), 403-409.

Rodenbusch, S. E., Hernandez, P. R., Simmons, S. L., \& Dolan, E. L. (2016). Early engagement in course-based research increases graduation rates and completion of science, engineering, and mathematics degrees. CBE Life Sciences Education, 15(2), ar20.

Russell, J. E., D'Costa, A. R., Runck, C., Barnes, D. W., Barrera, A. L., Hurst-Kennedy, J., ... Iskhakova, L. A. (2015). Bridging the undergraduate curriculum using an integrated course-embedded undergraduate research experience (ICURE). CBE Life Sciences Education, 14(1), ar4.

Schultz, P. W., Hernandez, P. R., Woodcock, A., Estrada, M., Chance, R. C., Aguilar, M., \& Serpe, R. T. (2011). Patching the pipeline: Reducing educational disparities in the sciences through minority training programs. Educational Evaluation and Policy Analysis, 33(1), 95-114.

Seymour, E., Hunter, A.-B., Laursen, S. L., \& DeAntoni, T. (2004). Establishing the benefits of research experiences for undergraduates in the sciences: First findings from a three-year study. Science Education, 88(4), 493-534.

Thiry, H., \& Laursen, S. L. (2011). The role of student-advisor interactions in apprenticing undergraduate researchers into a scientific community of practice. Journal of Science Education and Technology, 20(6), 771-784.

Thompson, J. J., Conaway, E., \& Dolan, E. L. (2016). Undergraduate students' development of social, cultural, and human capital in a networked research experience. Cultural Studies of Science Education, 11(4), 959-990.

Thompson, J. J., \& Jensen-Ryan, D. (2018). Becoming a "science person": Faculty recognition and the development of cultural capital in the context of undergraduate biology research. CBE Life Sciences Education, 17(4), ar62.

Trenor, J. M., Miller, M. K., \& Gipson, K. G. (2011). Utilization of a think-aloud protocol to cognitively validate a survey instrument identifying social capital resources of engineering undergraduates American Society for Engineering Education.

Trott, C. D., Sample McMeeking, L. B., Bowker, C. L., \& Boyd, K. J. (2020). Exploring the long-term academic and career impacts of undergraduate research in geoscience: A case study. Journal of Geoscience Education, 68(1), 65-79.

Villarejo, M., Barlow, A. E., Kogan, D., Veazey, B. D., \& Sweeney, J. K. (2008), Encouraging minority undergraduates to choose science careers: Career paths survey results. CBE Life Sciences Education, 7(4), 394-409.

Wang, S. (2019). A student's guide to undergraduate research. Nature. https://doi. org/10.1038/d41586-019-00871-x.

Wenderholm, E. (2004). Challenges and the elements of success in undergraduate research. ACM SIGCSE Bulletin, 36(4), 73-75.

Wigfield, A., Tonks, S., \& Klauda, S. L. (2009). Expectancy-value theory. In Handbook of Motivation at School, (pp. 55-75).

Wood, W. B. (2003). Inquiry-based undergraduate teaching in the life sciences at large research universities: A perspective on the Boyer commission report. Cell Biology Education, 2(2), 112-116.

Yosso, T. J. (2005). Whose culture has capital? A critical race theory discussion of community cultural wealth. Race Ethnicity and Education, 8(1), 69-91.

\section{Publisher's Note}

Springer Nature remains neutral with regard to jurisdictional claims in published maps and institutional affiliations.

\section{Submit your manuscript to a SpringerOpen ${ }^{\circ}$ journal and benefit from:}

- Convenient online submission

- Rigorous peer review

- Open access: articles freely available online

- High visibility within the field

- Retaining the copyright to your article

Submit your next manuscript at $\boldsymbol{\nabla}$ springeropen.com 